RESEARCH PAPER

\title{
The Organization of Islamic Cooperation (OIC): Challenges for the Islamic World
}

\author{
1Dr. Ghulam Mustafa* 2 Nusrat Bano
}

1. Assistant Professor, Department of Political Science and International Relations, Government College University Faisalabad, Punjab, Pakistan

2. PhD Scholar, Department of Political Science and International Relations, Government College University Faisalabad, Punjab, Pakistan

\begin{tabular}{|c|c|}
\hline PAP & \\
\hline 2020 & $\begin{array}{l}\text { Unified platform is guaranteed to collective efforts for mutua } \\
\text { cooperation and prosperity. The mutual cooperation and collaboratio } \\
\text { bring stability and development among member countries. Internally } \\
\text { Muslim world is suffering under bad governance, corruptior } \\
\text { malpractices, poverty, backwardness, ignorance, social injustice }\end{array}$ \\
\hline $\begin{array}{l}\text { overnance, } \\
\text { mic } \\
\text { jardness, } \\
\text { phobia, } \\
\text { ialism, } \\
\text { ianism, }\end{array}$ & $\begin{array}{l}\text { most of the countries of the Islamic world. While, externally } \\
\text { western aggression, Islamophobia and anti-Islamist propaga } \\
\text { Kashmir, Palestine and misbehave with Muslim minorities by the } \\
\text { countries are another challenges. Some other factors which incr } \\
\text { distrust among them are internal sectarian and territorial rivalry } \\
\text { example, both Iran and Saudi-Arabia have aggressive policy aga }\end{array}$ \\
\hline 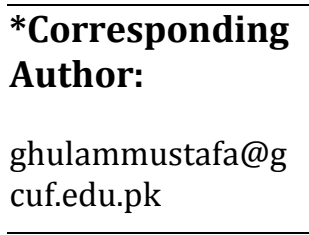 & d Statec (UIS) Role of Oroanization \\
\hline
\end{tabular}

Introduction

Unity is the pre-requisite for developing relations and enhancing cooperation among nations. Its details may be subjective in socio-political and economic development. Islam is the religion which preaches peace, love, brotherhood among mankind particularly to Muslims. In the contemporary world affairs, cooperation and relation at regional and international level not only bring stability and interdependence but also united the world protecting their economic and diplomatic interests. The Muslim World, which comprises almost one fourth of the world population, has a natural propensity for cooperation within itself. Muslim ruled for a long time at major part of the world. But since last centuries, they have deprived of their glory period due to internal conflicts and external conspiracies. Likewise, the conflict between Iran and Saudi Arabia to gain regional hegemony makes situation more complex. Sectarian conflicts and civil unrest also creates problems building relations among Islamic world. In most of the Middle Eastern countries, traditional type of 
governments can be caused of anti-government sentiments and internal as well as external unrest.

Historical and traditional religious identity provides the unique platform of Organization of Islamic Cooperation (OIC) to Muslim world. The representative Islamic forum is consists of 57 Muslim countries, they set their mutual aims and objective in the charter of the organization promoting and protecting their sovereignty, unity and solidarity as well as securing their mutual and common interests at world level. They have desire to cooperate in different fields including socio-cultural, economic, scientific and technological development under the shadow of collective efforts. Currently, the mutual platform OIC is considered incompetent to provide utility, achieve their goal due to mutual distrust, emerging new challenges like extremism, terrorism, lack of political will, and internal disputes. Even though, the internal body is not capable to determine agenda, recommendations and resolutions of the OIC (Siddiqa, 2016).

The organization shares regional, historic, cultural and ethnic identities but failed to maintain peace, to reduce tension at regional as well as international level.

\section{Challenges: Reasons behind it and its Impacts on Muslim Countries}

Politically, there are so many failures in the political system of Muslim countries. They are lack of institutional building. In most of the Muslim countries, there is no balance between the institution of executive and military. Muslim countries have failed to define role of Islam in politics and economic governance. Moreover, the political system has not ability to transfer power from authoritarian rule to representative government.

The decline of Islamic world has multi-dimensional matters. It detail may be subjective in the moral, the social, the political, the economic and historical perspectives. Early Muslims have enjoyed good character, moral values and teaching of Quran which contributed to rise of glorious Muslim time period. Some ancient and modern philosophers have stated about it. Morally, the most important factor behind fall of Muslim community is the human himself also, because human being is considered that they are not only the end but also the means of their development, The Qur'an clearly states that "God does not change the condition of a people until they change their own innerselves" (13:11).

Socially, unequal distribution of wealth deprives the people to equal opportunities which can be decline of social solidarity as well as civil unrest. Politically, illegitimate rulers possess traditional ruling behavior which restricts freedom of thoughts and expression. It can be caused of revolt against government and unrest for the whole region. Economically, unhealthy socio-political environment not gives the birth of healthy and stable economy which makes Muslim population less advanced and under-develop (Chapra, 2007).

Muslim of the world is living under the horrible condition. Despite of all natural resources, neither the rulers nor their people have the plan of social, democratic, progressive and welfare state. As compared, western countries rapidly seems to progress in all sphere of life. Backwardness is not a healthy sign in most of the Muslim societies, many Muslim societies are based on patriarchal and conservative minded people where women are marginalized to take decision independently and to get education with their own will which neglects political participation, rights and liberties. Islam believes on rule of law, equality and fundamental rights but it is neglected massively. 
The other alarming challenges are of extremism, corrupt practices, bad governance, extreme poverty, illiteracy, poor economic growth, prevalence of dictatorship, inability to compete new emerging challenges and technology and non existence of dynamic, effective as well as influential leadership. On that result, Islamic world are facing the depressed and dishearten situation which gradually weakened them intellectually, emotionally spiritually even in every aspect of their lives. They are unable to compete and feel powerless as a member of society which developed the feeling of self-alignment and deprivation (Ariffin, 2017).

In the universe, Allah Almighty has sovereign power. Man was created by the Allah (SWT) as his khalifah who has the ability to be creative, active, intellectual, critical, analytical and judicious etc. This intellectual or mental faculty is mentioned in Surah AlBaqarah 31-33 when Allah (SWT) decided to create a khalifha on earth (Ariffin, 2017).

The socio-cultural diversity and religious fundamentalism are other causes of rivalry. Firstly, gender relations in Kazakhstan are structured in different way rather than Egypt and Saudi Arabia which can be caused of clash among different cultural identities. Secondly, acceptance of socio-cultural "hybridity" or ambitious to replace by "authencity" with purity of Islam can be caused of challenge to Globalization and emergence of fundamentalist movement in Muslim countries. Religious fundamentalists counter the process of modernization and neglect the multi cultural Muslim society. For example, Islamic scholar Azyumardi Azra has stated that Islamic radicals of Indonesia have the perception that indigenous Indonesians Islam is hybrid in nature which should be transformed and purified into authentic Islam (Hassan, 2011).

Recently, despite of lookdown in Indian-held Kashmir, the Indian Prime Minister Narendra Modi has been honoured with highest civilian award both by the Saudi Arabia and (UAE) due to his record efforts enhancing bilateral trade relations. The Gulf countries have ambitious to take part in Indian largest market. New Dehli based research observer claimed that annually, Saudi Arabia has more than $\$ 100$ bn trade relations as well as UAE has $\$ 55 \mathrm{bn}$ with their Indian bestowed (Kuchay, 2019).

The Gulf countries have multifaceted relations with India including trade, military assistance and realistically, Kashmir issue or right of self-determination of Muslims of Kashmir is not the top agenda of the Gulf States. They are not looking for the sovereignty and security of the whole Muslim world. Even, other countries Kuwait, Bahrain, Qatar and Oman did not issued public statement about Indian brutality on occupied Kashmir

\section{Relations among Muslim Countries in the Contemporary World}

The stability and prosperity of the Middle East region is dependent on the relations between Saudi Arabia and Iran. The relations between Saudi Arabia and Iran remained tense creating distrust, misunderstanding between two countries since emergence of revolution of Iran. The Islamic revolution in Persia established the Shiite ideological based government led by Ayatollah Khomeini as contradict to Wahabism led by Saudi Arabia. Prior to it, during the time of pahlavi dynasty both countries remained cooperative relations. Even, both countries served the pro-Western and pro- United States monarchies. Currently, escalating tension between them has divided Arab world into two blocs. They have divided the region raising their greater involvement in the proxy war and 
alliances which not only shattered the Arab countries but also raises many questions about the stability and unity of the whole Islamic world.

Initially, supreme leader of Iran stated against the Saudi led monarchy and argued it was against the will of the Islam. He opposed practicing that form of government in the entire region. On the contrary, Arab states (monarch states) considered that Iran had bad ambition against them they observed that Iran had a policy to spread its ideology countering Saudi led monarchy as well as wanted regional hegemonyto stop US influence and kicking back Israel. Both countries made further public statement to counter each other which developed the tense relationship between Tehran and Riyadh.Some other incident increased more distrust among Arab countries. For example, in time of Iran-Iraq war, Saudi Arabia provided moral, economic, military and diplomatic support to Iraq to sabotage the sovereignty of the Iran.Furthermore, the Gulf States established Gulf Cooperation Council (GCC) comprise of Qatar, Oman, United Arab Emirates (UAE), Kuwait and Bahrain to safeguard their sovereignty during war (Ali \& Fozia, 2018).

The emerging humanitarian crisis in Yemen has been associated with the rivalry of both countries Iran-Saudi Arabia. Historically, Yemen is a poor country, the poor people of poor country have been suffering with massive devastation, famine, disease, displacement and casualties since operation was launched led by Saudi Arabia coalition. Both the Saudi led alliance and rebels have been blamed to killing civilians in ruinous war. The crisis erupted; the internationally recognized government has been toppled by the Houthi rebels that were the result of discriminative civilian death tool. The Inter-Agency Standing Committee declared emergency in Yemen in July 2015; and estimated that around twothirds of the population is in need of aid, with almost 40 percent in sever need. Women, children, ethnic and religious minorities, and internally displaced persons are particularly vulnerable (Coppi, 2018).

Unlike others conflicts, Syrian uprising started with anti-government protest against president Bashar-al-Assad dynasty. The peaceful protest led by opposition was suppressed by the government who demanding reforms about socio-economic and political development for the country which was transferred into violent civil war. It involved many internal and external key actors directly or indirectly. Like other regional conflicts, Syrian crisis also labeled to two regional powers, the Shiite forces led by Iran and Sunni coalition led by Saudi Arabia.The some other international key actors also were involved in it. Likewise, Russian military support, involvement of Kurdish fighters and participation of Islamic State into Iraq and Syria (Tan \& Perudin, 2019).

Since partition of the sub-continent, Kashmir is a major dispute between India and Pakistan. India forcefully occupied the territory of the Kashmir through its forces pushing their rights of self-determination. Since that time, people of the Kashmir have been demanding their right of self determination to decide about their political future. Pakistan has been condemning Indian brutality since its occupation. Historically, population of Kashmir valley consists of Muslim majority. They have social, religious, cultural and geographical link with Pakistan. The first war between Indo-Pak has been occurred over Kashmir dispute which divided the territory into two regions. Indian occupied territory and smaller area with Pakistan in case of cease fire under the shadow of United Nation resolution in 1949. Both independent countries, India and Pakistan claimed sovereignty over Kashmir valley at the forum of world United Nations (UN) and had fought many times over Kashmir (Majid \& Hussain, 2016). 
The Palestine-Israel conflict has another major issue on the map of the world. The world platform (UN) divided the region between two states in 1947.Since that time, people of Palestine have been struggling for their own land. On the other hand, Israel has desire to capture more land considering that division was not satisfactory. This hypothesis makes situation more complex. The rights of self-determinations and right of freedom are violated since inception of division and makes region most frustrated, intense and conflicting zone. Many times, terrorist activities have been launched by the Israel to sabotage the sovereignty of the Palestine. On the other, Palestinian resist against Israel brutality to counter its terrorist activities and to protect their territory. Historically, the Muslim of the whole world has sacred-religious association with the region of Palestine and Muslims of the world have religious sentiment with people of Palestine and their land (Said, 2018).

Rohingya crisis is the worst humanitarian crisis consisting of minority Muslim group in the Myanmar. It is a process of ethnic- cleansing which were started by the predominantly Buddhist country. The discriminatory policies were made to force them to leave their county. Even though, cases of murder, rape, murder, and arson have been reported continuously since late 1970 . On that reactions, most of people migrated to others countries including Bangladesh, Indonesia, Malaysia, and Thailand. According to recent report of the United Nations Human Rights Commission Report (UNHCR) more than 700,000 refugees and internally displaced people are living inside camps of Cox"s Bazar District of Bangladesh under the condition of stateless society. Moreover, ethnic Muslim minority in Myanmar in their province 'Rakhine' are under the least develop region of their country, with below poverty rate, less economic opportunities, poor infrastructure (Hossain \& Hosain, 2019).

\section{Need to Enhance Cooperation among Muslim Countries on the Platform of (OIC)}

Muslim unity is the undeniable demand of the present Islamic world. Muslim world is facing many challenges. Now a day, Muslims of the world have been emphasized to awake to secure their religious, cultural, moral values countering their enemies.Western aggression is the major challenge involving various contributors to expose the negative image of the Islam. Anti-Islamist propaganda is made by many segments of the western society including western extremists to their own personal interests, politicians to attract their voters, scientists, generalists and religious extremists to protect their ideology, interests and demands. Such behaviors are differentiated on religious and cultural basis (Shadid \& Koningsveld, 2001).

In present century, globalization is worldwide phenomenon. It is process of dominating the political, economic and social segments of the country through international trade, information technology, media and international defense. In contemporary Islamic world, it creates problems and promotes major challenge because of less advancement and under-development. In other words, it can be called a process of colonialism and imperialism towards Islamic states. On that result, contemporary Muslim countries face an incompetent position rather than a partner.This approach stresses the need on Islamic unity. It is the extreme need of the contemporary world, to promote and secure more solidarity, identity, security and defense by adopting the culture of cooperation.

\section{To counter Islamophobia}


Basically, Islamophobia is refers to discriminate behavior toward Muslims by the non- Muslims communities. Some theorists define its new term of 'Racism' and some claimed that Islamophobia was labeled by the Western liberal mindset groups who believed on the agenda of secularization and could not accept religious influence like Islam to propagate their own ideology. They further argued that anti Muslim sentiments were related to the limits of pluralism and multiculturalism in the West.

Moreover, Western countries portrayed the image of the Islam as hostile religion. They believed that Islam had preached terrorism and fundamentalism and hate- ideology towards others. Recently, hate-filled terrorists targeted Muslims in Christchurch mosque in New Zeeland. It not only horrified the Muslims but also started new discussion on religious terrorism, white supremacist, racism, hate and prejudice against refugees, gun laws etc. it is considered that reasons behind this attack increasing perception of Islamophobia, hating behavior towards Islam and hate crime against Muslims. Since the 9/11 attentions of the Western media has been diverted to Islam which exposed that Islam is the second name of terrorisms and Muslims are perpetrators and aggressors. Every incident or attack has been associated with Islam as a religion of fundamentalism, terrorism and extremism (Ciftci, 2012).

It is the dire need of the Islamic world to present counter message towards antiIslam. In anywhere the strength of the society lie in diversity. It is mandatory for Muslim world to take effective policy to counter negative image by digital technology and social media. Islamophobia must be countered through analysis and research on host communities and to address causes which is result of religious hatred. It is the need of contemporary age, to increase investment in education. It is the only source that born the culture of peace and tolerance. The reason should also be found in the politics of the Muslim countries not religions or civilizations.

\section{To Resolve Territorial or Internal Disputes}

The relations among oil rich countries revolves around it internal politics, geographical situation, cultural factors and territorial disputes. The situation is that, they compete with each other to sabotage the sovereignty of the other involving and interfering formal and non formal actors. Moreover several small issues are also considered against the unity of Muslim countries. For instance, the sovereignty of Nigeria was threatened by the extremist group of Boko Haram as well as has been sovereignty of Pakistan, Afghanistan, Sudan and Somalia were challenged by the so-called naming Islamist rebel groups (Gleditsch \& Rudolfsen, 2016).

The whole Muslim world from Saudi Arabia to Indonesia to Pakistan was drawn in terrorist activities. Likewise, Pakistan has spent more time in dismantling, combating, and battling terrorist activities rather than stabling its socio-economic segments. Unfortunately, the local political, economic and social demands more intensified situation involving sectarian and ethnicity in the conflict. The ethnicity and socio-cultural diversity are others challenges within Muslim states. Since the fall of Ottoman Empire, Kurdish dispersed across Iraq, Iran, Syria and Turkey are struggling for their separate country and cause of dispute and violence. Even in our country Pakistan, many ethnic communities hurdle to run the government and country smoothly. Sectarianism is also alarming cause, it can be date backs 
from revolution of Iran and soviet invasion of Afghanistan. This is the result of rivalry between Shia and Sunni groups. It has involved many militant organizations, states, wars and western allies in the conflicts. These so-called conflicts not only weakened the Muslim states but also threatened the dream of pan-Islamism. In contemporary world, OIC live beyond the expectations of its manifesto. The charter of OIC guarantees the right to selfdetermination and non interference in the internal matters of its member states but it is violated by its signatories.

\section{To Positive Sign on the Issue of Palestine}

Palestine issue is another Islamic cause which involved the whole Islamic world to protect the legitimate rights of the Palestinian people by condemning Israel brutality. In the manifesto of the OIC the core duty it to safeguard sovereignty of its member states, but due to internal weakness this goal could not be achieved.

Like internal maters the role of OIC is also harder in external conflicts. Since its establishment, more than 2300 resolutions have been adopted to boycott economic, diplomatic relations with Israel but failed to implement it (Hanif, 2014).

\section{To Positive Sign on the Issue of Kashmir}

Since the partition of Sub continent, Kashmir cause is also burning question because refusal of its people as parts of Indian boundary and inevitably part of itself as the agenda of Pakistan as well as Islamic nation.

The collective representation of Islamic world is long in idiom but short inactions. The main objective of organization of OIC to counter western aggression with one voice is not present and it proved toothless tiger to combat external conflicts. As well other matters, resolutions about Kashmir were passed and Indian brutality was condemned officially but practical decisions were not taken to counter it (Castillo, 2014).

\section{To The Protection of Rights of the Muslim Minorities}

Moreover, the Rohingyias Muslim minority community is being victimized and discriminated by the Non-Muslim country. The Islamic world and OIC immediately have not interest to develop diplomatic mechanism as well as used world forum to protect them from non-Muslim state's brutality.

\section{To Eradicate Militancy, Terrorism, Extremism}

To eradicate proliferation of militancy through negotiation and dialogue process should also be started with the leaderships of these organizations building peace and prosperity. The others, prosperity and stability and sectarian and ethnic division should be secured through social justices, economic equality and political rights and insure legitimacy as well as full-fledged public participation.

\section{Analysis of Organization of OIC and Challenges of the Islamic World}

Historically, OIC is the product of meeting in Rabat Morocco, where the head of the states of many Muslim countries including king of Morocco and representative of 25 Muslim countries met together to discuss incident of Al Aqsa Mosque which established the 
collective Islamic platform. Later, the foreign minister of many Islamic countries met in Jeddah (Saudi Arabia) to adopt its agenda defining its aims and objectives in 1970. Since now, It is considered pre-requisite for collective security and defense but the Muslims of the world neglect its importance. Having difference, Islamic world has rich with religiouscultural affinity. But more than one decade, multi-dimensional internal and external matters have been contributed behind to Muslim disunity. Arab spring is also intensified the situation of Middle East increasing the sectarian fault line, creating a fertile ground for militant organizations. The main primary challenges of OIC as well as Muslim countries are lack of democracy, collective Islamic defense, effective leadership and societal development which are collectively responsible of marginalization of Muslim world in International affairs. However, the mutual platform of Islamic states is not considered successful achieving their set goals and effective rule-maker in global politics due to lack of cooperation among their countries. Its formal structure has lot of weakness including lack of rule-enforcing body. As compared to body of United Nations (UN), and other Organizations, OIC is a "relatively unstructured organization" it is neither comprehensive nor institutionalized within its structure. Although, it is the collective representative body of the whole Islamic world but it is not strong as its nature. It always seems as a conference diplomacy having complex decision making process with limited capacity to enforce rule which make it helpless. Even though, the presence of head of states and government, kings of the countries and council of foreign minister and General Secretary could not strengthen its real authority in decision making process. Moreover, establishment of organ of International Islamic Court of Justice was remained pending since 1981 meeting of OIC. The (IICJ) might be the most encouraging organ in rule-enforcement and enactment process. If, the establishment of that organ will be possible, it would be the highest enacting judicial organ of the OIC. The article 38 of the charter of OIC bound involving parties to accept its final judgments and according to article 39 these judgments could not be appealed. But it would be possible when all members ratify its charter. Furthermore, imposition of sanctions is not present in charter of OIC. The Organization is the only platform of discussion, resolution on the issue of Palestine, Kashmir, globalization, Terrorism and Extremism and passing only hollow declarations. With all those things, collective platform of the Islamic world has important position around the world due second largest organization of the world, that's way many regional organizations and non Muslim states have show interest to be observer status including Russia and China. It is growing need that OIC must be met with the contemporary world challenges effectively and comprehensively, otherwise it would threat of its identity. It will also address its weakness in to all aspects and suggest recommendation both for structural and ideological basis which make it practical like others successful organizations.

\section{Conclusion}

It is concluded that Muslim world has multi-dimensional challenges both within and outside of their countries. The aim to strength OIC through collective efforts is still a myth in Islamic world. Historically, the most of Muslim countries have bilateral collaborative relations rather than mutual cooperation among all of them.The implementation of ideology of Muslim brotherhood and protection of Islamic values are not the top priority of Islamic world. All nations have their own materialistic interests with other non Muslim nations. It should be the first priority of the representatives of Muslims to control the rise of Islamophobia. OIC must stand recognize it as a serious phenomenon and present comprehensive plan to tackle this situation across the globe. Muslim world 
should also address the sensitivity found on the floor of the UN that Islam is the religion of tolerance rather than extremism. Unfortunately, The Muslims of world have failed to fulfill their basic need of advancement in technology. Unless, the member of so-called Islamic organization will not address their challenges and apply their political will in international affairs, they will not succeed. The crisis between West and Islam is resolved by playing constructive role through an informed dialogue among different faiths. 


\section{References}

Ali, L. A., \& Fozia. (2018). Iran-Saudi Relations: From Rivalry to Nowhere. Global Social Sciences Review , 49-57.

Ariffin, A. (2017). Revisiting the Malaise of the Ummah: A Way Forward. Advanced Science Letters , 4990-4992.

Ashimi, T. A. (2016). Islamic Civilization: Factors behind its Glory and Decline. International Journal of Business, Economics and Law, 180-184.

Castillo, V. L. (2014). The Organization of Islamic Cooperation in Contemporary International Society. The Organization of Islamic Cooperation in contemporary international society, 1-21.

Chapra, D. M. (2007). Muslim Civilization: The Causes of Decline and the Need for Reform. , Islamic Research \& Training Institute Development Bank, Jeddah, Saudi Arabia, 1-3.

Ciftci, S. (2012). Islamophobia and Threat Perceptions: Explaining Anti Muslim Sentiment in the West . Journal of Muslim Minority Affairs, 1-22.

Coppi, G. (2018). The Humanitarian Crisis in Yemen:Beyond the Man-Made Disaster. International Peace Institute., 1-40.

D. İ., \& Hammour, J. (2018). The Arab League: From Establishment to Failure. Social and Legal Studies, 34-37.

Gleditsch, N. P., \& Rudolfsen, I. (2016). Are Muslim countries more prone to violence? Research and Politics, 1-9.

Hanif, R. A. (2014). Pakistan, Oic and The Challenges of Muslim World. Journal of Punjab University Historical Sciences, 47-57.

Hassan, R. (2011). Modernization, Social Change and Religion: A case study of the Islamic Ummah. Academic Articles in Lahore School of Economics Journals, 49-58.

Hossain, M. S., \& Hosain, M. S. (2019). Rohingya Identity Crisis: A Case Study. Saudi Journal of Humanities and Social Sciences, 238-240.

Kuchay, B. (2019, 9 12). Why have Saudi Arabia, UAE failed to condemn India over Kashmir? Retrieved from Aljazeera.com: https://www.aljazeera.com/news/2019/09/saudiarabia-uae-failed-condemn-india-kashmir-190911112648176.html

Majid, A., \& Hussain, M. (2016). Kashmir: A Conflict between India and Pakistan. A Research Journal of South Asian Studies, 49-57.

Said, M. J. (2018). The Palestine-Israel Conflicts. Research Gate, 1-14.

Shadid, W., \& Koningsveld, P. v. (2001). solutions, The negative image of Islam and Muslims in the West: Causes and Solutions. The position of Islam in the European Union, 174-195. 
Siddiqa, A. (2016). The Utility of the OIC in Solving Conflicts in the Muslim World. Institute of Strategic Studies, 1-5.

Tan, K. H., \& Perudin, A. (2019). The "Geopolitical" Factor in the Syrian Civil War: A Corpus-Based Thematic Analysis. Journal of Analytical Science and Technology, 1-15. 